Research Article

\title{
Evaluation of the in vivo anti-plasmodial activity of ethyl- acetate extract of Cassia occidentalis leaf in Plasmodium berghei - infected mice
}

\author{
Maimuna Bello Umar ${ }^{* 1}$, Halimat Abdulsalami ${ }^{2}$ Rasaq Bolakale Isiaq ${ }^{1}$, Nwamaka \\ Maureen Odu' ${ }^{1}$, Fatima Mahmoud Muhammad ${ }^{1}$
}

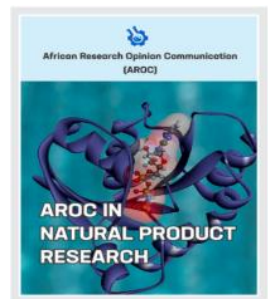

\author{
${ }^{1}$ Department of Biochemistry, School of Life Sciences, Federal University of Technology Minna, Niger \\ State, Nigeria. \\ 2Department of Plant Biology, School of Life Sciences, Federal University of Technology Minna, Niger \\ State, Nigeria.
}

Corresponding author: Maimuna Bello Umar: maimuna.umar@futminna.edu.ng Received: 07 December 2021, Revised: 11 February 2022, Published: 28 February 2022 https://doi.org/10.53858/arocnpr02011320

\begin{abstract}
Background: Malaria is undoubtedly one of the world's deadliest infectious diseases. It is a widespread disease that continues to be associated with considerable morbidity and mortality with a significant social and economic impact in developing countries. This study was aimed at evaluating the therapeutic effect of the ethyl acetate extract of Cassia occidentalis in Plasmodium berghei infected mice. Methods: Qualitative phytochemical screening was carried out, using standard methods. Acute oral toxicity ( $\left.L_{50}\right)$, as well as both suppressive and curative antiplasmodial test, was carried out. Results: Flavonoids, saponins, steroids, tannins and phenolic compounds were found to be present in the extract. The median lethal dose $\left(L_{50}\right)$ was calculated to be $\geq 5000 \mathrm{mg} \mathrm{kg}-1$ body weight. Percentage suppression of parasitaemia was calculated to be $37.84,42.84,77.88,83.06$ and $0.00 \%$, with mean survival period (in days) of $6.00 \pm 0.58,12.33 \pm 1.45,26.33 \pm 2.03,29.00 \pm 1.00$ and $4.33 \pm 0.88$ for groups treated with $100,200,400$ $\mathrm{mg} \mathrm{kg}-1$ bodyweight of the extract, $5 \mathrm{mg} \mathrm{kg-1}$ body weight of chloroquine and negative control group respectively. The percentage inhibition of parasitaemia in the curative test was calculated to be $42.38,47.67,79.17,81.99$ and $0.00 \%$, with mean survival period (in days) calculated to be $7.67 \pm 1.45,15.00 \pm 1.73,25.33 \pm 1.86,29.00 \pm 1.00$ and $5.00 \pm 1.53$ for groups treated with $100,200,400 \mathrm{mg} \mathrm{kg}-1$ bodyweight of the extract, $5 \mathrm{mg} \mathrm{kg}-1$ body weight of chloroquine and the negative control group respectively. It was observed that there was a significant $(p<0.05)$ increase in percentage packed cell volume (PCV) in the treated groups compared to the untreated group. Conclusion: The result of this study showed that ethyl acetate extract of Cassia occidentalis leaf possess appreciable antiplasmodial effect and justifies its traditional use as an herbal remedy against malaria and may, therefore; offer a potential drug lead for the development of a safe, effective and affordable antimalarial.

Keyword: Antiplasmodial; Cassia occidentalis; ethyl-acetate extract; Plasmodium berghei, malaria; LD50

Citations: Umar, M.B., Abdulsalami, H., Isiaq, R.B., Odu, N.M., and Muhammad, F.M. (2022). Evaluation of the in vivo anti-plasmodial activity of ethylacetate extract of Cassia occidentalis leaf in Plasmodium berghei - infected mice. AROC in Natural Products Research, 2(1);13-20, https://doi.org/10.53858/arocnpr02011320
\end{abstract}

\subsection{Introduction}

In 2020, there were an estimated 241 million cases of malaria worldwide, with an estimated number of malaria deaths at 627,000 [1]. More than 2 billion people are at risk of malaria [2] which is endemic in 91 countries predominantly in Africa, Asia, and Latin America. Four African countries accounted for just over half of all malaria deaths worldwide: Nigeria (31.9\%), the Democratic Republic of the Congo (13.2 $\%)$, the United Republic of Tanzania (4.1\%) and Mozambique (3.8 \%).

In the late 1940 s, chloroquine was massively used and accepted Worldwide but resistance has spread to the vast majority of the malaria-endemic regions like Africa, South East Asia and East Asia [3]. A combination of the Antifolate drugs, Sulfadoxine, Pyrimethamine, soon became choice antimalarial widely used because it was inexpensive. This drug also faced unacceptable levels of therapeutic failure in many countries in South America, Asia and more recently Africa [4]. Resistance to mefloquine has become an issue in Cambodia, Myanmar, and some border areas of Thailand. Whereas in some areas like Brazil and South East Asia where quinine and tetracycline are used in combination for treating uncomplicated malaria, sensitivity to quinine is seriously diminishing [5]. Hence, the problem of resistance of plasmodium to antimalarials in malariaendemic regions of the world has left this region with an unprecedented situation in which the few and affordable treatment options are rapidly losing therapeutic efficacy [6]. 
In recent years, antimalarial drug resistance has emerged as a threat to global malaria control efforts. Regular monitoring of drug efficacy is needed to inform treatment policies in malaria-endemic countries and to ensure early detection of, and for response to, drug resistance. Discovering new antimalarial compound is more than ever a priority due to the alarming rate of resistance to available drugs and the limited number of effective antimalarials [7]. Plants are usually considered to be possible candidates as an alternative and rich source of new drugs. The majority of the populations in many tropical countries depend on traditional medical remedies using herbs [8].

Different parts of Cassia occidentalis have been reported to possess medicinal properties; $C$. occidentalis plant leaf has been extensively used in indigenous and folk-lore medicine systems. In the Indian system of medicine, the plant has been documented as thermogenic, expectorant, diuretic, and used in the treatment of leprosy, ulcers, cough, bronchitis, constipation, menstrual problems, tuberculosis, and anaemia [9] reports for it immunosuppressive [10] antibacterial [11] and antiplasmodial [12]. Considering the therapeutic values of $C$. occidentalis, the present work was undertaken to evaluate the acute toxicity and the antiplasmodial property of Ethyl-acetate extract of Cassia occidentalis.

\subsection{Materials and Methods}

\subsection{Collection of Plant Samples}

Fresh leaves of Cassia occidentalis were collected from Bosso, Minna, Niger State, Nigeria. The plant was identified by a Botanist in the Department of Plant Biology, Federal University of Technology, Minna, Niger State Nigeria.

\subsection{Experimental Animals}

This study was conducted in compliance with the Canadian Council on Animal care (CCAC, 1997) [13] to ensure the humane treatment of all experimental animals. Swiss albino mice of either sex weighing between 20 - $30 \mathrm{~g}$ obtained from the Nigerian Institute of Veterinary Research (NIVR) Jos, Plateau State, Nigeria were used for this study. They were fed with standard animal feed and water and maintained under standard conditions. The animals were allowed to acclimatize for two (2) weeks before being used for the experiment.

\subsection{Parasite}

The Plasmodium berghei used in this experiment was bought from National Institute for Pharmaceutical Research and Development, Idu industrial Layout, Abuja, Nigeria.

\subsection{Extraction of Cassia occidentalis}

The leaves of Cassia occidentalis were cleaned, dried and blended into a coarse powder. Ninety grams of the powdered sample was soaked in $600 \mathrm{~mL}$ of Ethylacetate and refluxed for 2 hours in a distillation flask mounted on a heating mantle according to the method described by Ugwu et al. [14] and Kabiru et al. [15]. The extract was filtered hot using a cheesecloth and the filtrate evaporated using a rotary evaporator and concentrated using a water bath. The crude extract was weighed and stored.

\subsection{Phytochemical Screening}

Phytochemical Screening for the extract was carried out according to the methods described by Tlukdar et al. [16]. The extract ( $2 \mathrm{~mL})$ was measured in a test tube to which picric acid solution was added. An orange colouration indicated the presence of alkaloids. The solution of the extract $(4 \mathrm{~mL})$ was treated with $1.5 \mathrm{~mL}$ of $50 \%$ methanol solution. The solution was warmed and metal magnesium was added to it, 5 drops of concentrated hydrochloric acid was added and red colour was observed for the presence of flavonoids. Five drops of concentrated $\mathrm{H} 2 \mathrm{SO} 4$ were added to $2 \mathrm{ml}$ of the extract. A reddishbrown colour indicated the presence of steroids. To a portion of the extract diluted with water, 3 drops of $10 \%$ ferric chloride solution was added. A blue colour was observed for gallic tannins and the green colour was observed for catecholictannins. The extract (1 $\mathrm{mL}$ ) was added to $1 \mathrm{~mL}$ of $10 \% \mathrm{FeCl} 2$ and mixed together. The presence of blue precipitate confirmed the presence of phenols. Saponins were detected using the froth test, $1 \mathrm{~g}$ of the sample was weighed into a conical flask in which $10 \mathrm{~mL}$ of sterile distilled water was added and boiled for 5 minutes. The mixture was filtered and $2.5 \mathrm{ml}$ of the filtrate was added to $10 \mathrm{~mL}$ of sterile distilled water in a test tube. The test tube was shaken vigorously for about 30 seconds. It was then allowed to stand for half an hour. Honeycomb froth indicated the presence of saponins.

\subsection{Determination of Acute Toxicity/LD50}

The method used to determine acute toxicity was that described by Lorke [17]. The study was conducted in two phases. In the first phase, three groups of 3 mice each were administered with the extract at respective oral doses of $10,100,1000 \mathrm{mg}$ per $\mathrm{kg}$ body weight. The mice were observed for signs of toxicity and possible deaths for 72 hours. In the second phase, another three groups of three mice each were administered respective doses of 1600, 2900 and $5000 \mathrm{mg}$ per bodyweight of the one for toxicity signs and deaths.

\subsection{Antiplasmodial Studies}

\subsubsection{Suppressive Test}

The Peter's 4 days-suppressive test was adopted against chloroquine-sensitive Plasmodium berghei NK - 65 infections in mice [18]. Swiss albino mice were 
inoculated by intraperitoneal injection with standard inoculums of Plasmodium berghei with 1 X 107 parasitized erythrocytes. The mice were then randomly divided into 5 groups made up of 3 mice per group and treated for 4 consecutive days using 100, 200 and $400 \mathrm{mg}$ extract per $\mathrm{kg}$ body weight. The extract was administered to three test groups respectively once daily for four days (Day 0, 1, 2 and 3 ). Two control groups were used; the positive control group was treated daily with $5 \mathrm{mg}$ chloroquine per $\mathrm{kg}$ body weight, while the negative control group was given an equivalent volume of sterile distilled water. On day 5 of the experiment, blood was collected from the tail vein of each mouse and smeared on a microscope slide in order to make a thin film [19]. The blood films were fixed using methanol and were stained with $10 \%$ Giemsa at $\mathrm{pH} 7.2$ for 10 minutes and parasitaemia examination was done using the electron microscope (x 100 magnification). The percentage parasitaemia was calculated for each dose level by comparing parasitaemia in the infected control (untreated) group with those treated; the result was presented as a percentage. Percentage suppression of the parasite was calculated by the following formula; Suppression (\%) $=$

mean parasitemia in negative control-mean parasitemia in treated mean parastiaemia in negative control $X 100$

\subsubsection{Curative Test}

The curative potential of $C$. occidentalis was done employing the method described by Ryley and Peter, [20]. The mice were injected intraperitoneally with standard inoculums of $10^{7} \mathrm{P}$. berghei NK- 65 infected erythrocytes on the first day (day 0 ). After 72 hours and following confirmation of parasitaemia, the mice were divided into 5 groups of 3mice per group. These groups were treated with the prepared leaf extract of Cassia occidentalis (100 200, $400 \mathrm{mg} / \mathrm{kg}$ body weight/day), chloroquine ( $5 \mathrm{mg} / \mathrm{kg} /$ body weight/day) was given to the positive control and an equal volume of distilled water was given to negative control group. The treatment lasted for 5 days at a single dose per day after which blood smears were collected and examined microscopically to monitor the parasitaemia level on these days in order to determine percentage growth inhibition of the parasite. Percentage growth inhibition of the parasite was also calculated by this formula; Curative $(\%)=$

$\frac{\text { mean parasitemia in negative control-mean parasitemia in treated }}{X 100}$ mean parastiaemia in negative control

\subsection{Estimation of Percentage Packed Cell Volume (\% PCV)}

This was carried out to monitor the level of Red blood cells in the course of the Experiment. The method employed was the method described by Dacie and Lewis [21]. The blood sample was collected from the tail of each mouse with a capillary tube by capillary action and sealed with a sealing agent (plasticine). The capillary tubes were then centrifuged, using a micro hematocrit centrifuge at $11,000 \mathrm{rpm}$ (revolution per minute), for 5 minutes. The \% PCV was then read using the micro hematocrit reader.

\subsection{Survival Time Determination}

Survival time was determined after the antiplasmodial test, for the period of 30 days and the days of survival for each group before death were recorded.

\subsection{Data Analysis}

Analysis was conducted in replicates and values were expressed as Mean \pm SEM. One-way ANOVA was used to analyze and the results were compared at a $95 \%$ confidence level. Values of $p<0.05$ were considered significant.

\subsection{Results}

3.1 Phytochemical constituents of the plant extract

The result of the phytochemical screening on Ethylacetate extract of Cassia occidentalis Leaf is represented in table 1 . Results revealed the presence of alkaloids, flavonoids, saponins, steroids, tannins and phenolic compounds. Resins were found to be absent.

Table 1: Phytochemical Constituents of Ethyl-acetate Extract of Cassia occidentalis leaf

\begin{tabular}{|l|l|}
\hline Phytochemicals & Results \\
\hline Alkaloids & + \\
\hline Flavonoids & + \\
\hline Saponins & + \\
\hline Steroids & + \\
\hline Tannins & + \\
\hline Phenols & + \\
\hline Resins & - \\
\hline Keys: $+=$ Present, - - = Absent & \\
\hline
\end{tabular}

\subsection{Median Lethal dose ( LD $\left._{50}\right)$}

Table 2 below shows the result of acute toxicity test (LD 50$)$ of ethyl-acetate leaf extract of Cassia occidentalis in mice. No mortality was recorded in any of the test groups in the two Phases.

Table 2: Median lethal dose $\left(L_{50}\right)$ of ethyl-acetate extract of Cassia occidentalis leaf in mice

\begin{tabular}{|c|c|}
\hline $\begin{array}{l}\text { Extract dosage } \\
\left(\mathrm{mgkg}^{-1} \text { b.wt) }\right.\end{array}$ & Mortality \\
\hline \multicolumn{2}{|l|}{ Phase I } \\
\hline 10 & $0 / 3$ \\
\hline 100 & $0 / 3$ \\
\hline 1000 & $0 / 3$ \\
\hline \multicolumn{2}{|l|}{ Phase II } \\
\hline 1600 & $0 / 3$ \\
\hline 2900 & $0 / 3$ \\
\hline 5000 & $0 / 3$ \\
\hline
\end{tabular}

mgkg-1 b.wt: mg per kilogram body weight 


\subsection{Antiplasmodial Activity}

\subsubsection{Suppressive Antiplasmodial Activity of} the Extract

Parasites were significantly suppressed in the groups treated with 100,200 and $400 \mathrm{mg} / \mathrm{kg}$ body weight in a dose-dependent pattern. Though the highest suppressive activity was observed for the standard drug (chloroquine) $(83.06 \%)$ there was no significant difference $(p>0.05)$ between its activity and that of $400 \mathrm{mg} / \mathrm{kg}$ body weight of the extract (Figure 1).

\subsubsection{Curative antiplasmodial activity of the} extract

The curative activity was also dose dependent for the extract as show in Figure 2. The standard drug
(Chloroquine) treated group however, showed the highest percentage decrease in the level of parasitaemia ( $81.99 \%)$ of treated mice

\subsection{Percentage Packed Cell Volume (\% PCV)}

The \% PCV of Plasmodium berghei infected mice used in the Curative study before induction, after induction and after treatment with the extract are presented in figure 3. Results revealed a significant reduction in \% PCV after Plasmodium berghei induction and increased significantly after treatment in the extract and chloroquine treated groups in a dose dependent pattern.

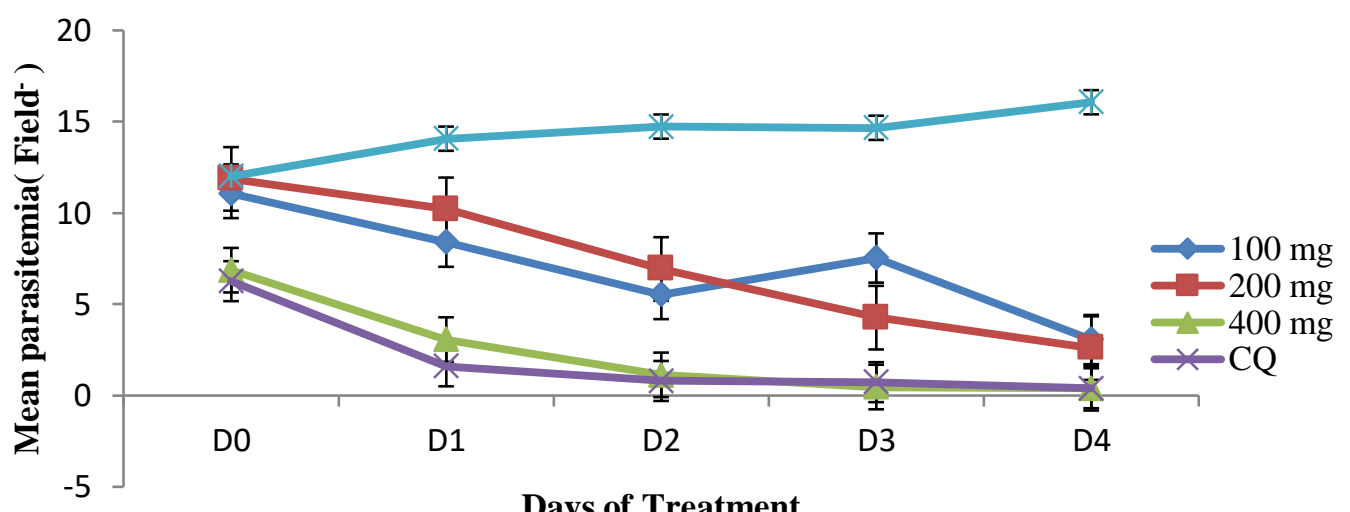

Figure 1: Suppressive antiplamodial effect of ethyl-acetate extract of Cassia occidentalis leaf in Plasmodium berghei-infected mice. CQ: $5 \mathrm{mg} / \mathrm{kg}$ Chloroquine, DW: Distilled Water. Each line point represents Mean \pm SEM of triplicate determinations

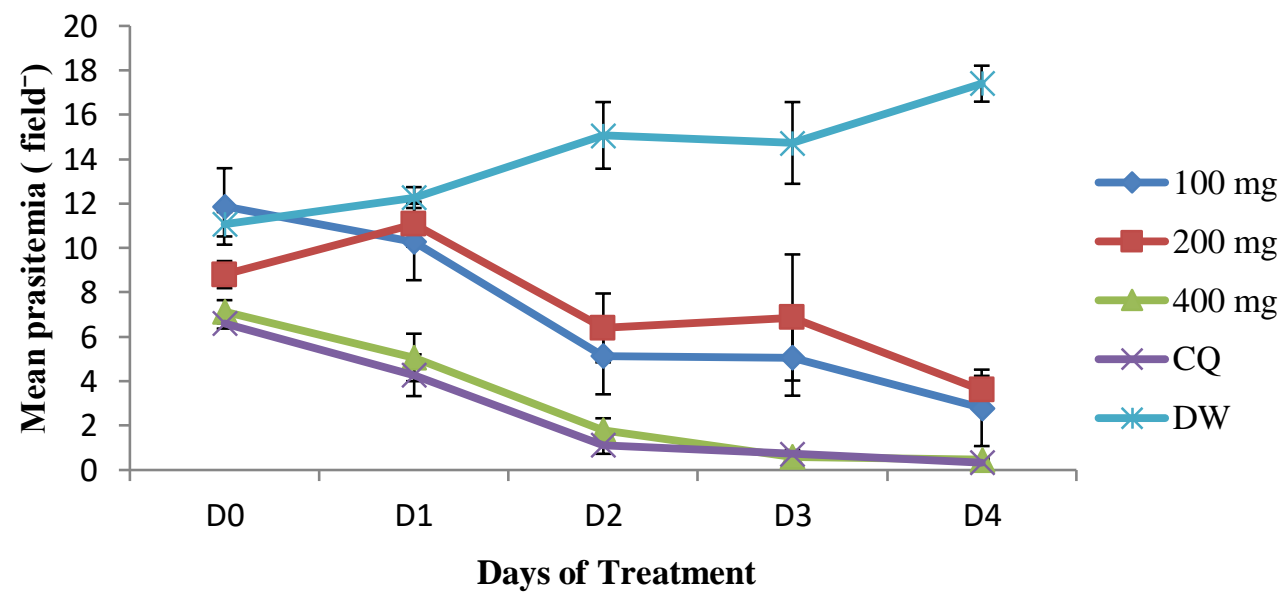

Figure 2: Curative Suppressive antiplamodial effect of ethyl-acetate extract of Cassia occidentalis leaf in Plasmodium berghei-infected mice. CQ: $5 \mathrm{mg} / \mathrm{kg}$ Chloroquine, DW: Distilled Water. Each line point represents Mean \pm SEM of triplicate determinations 


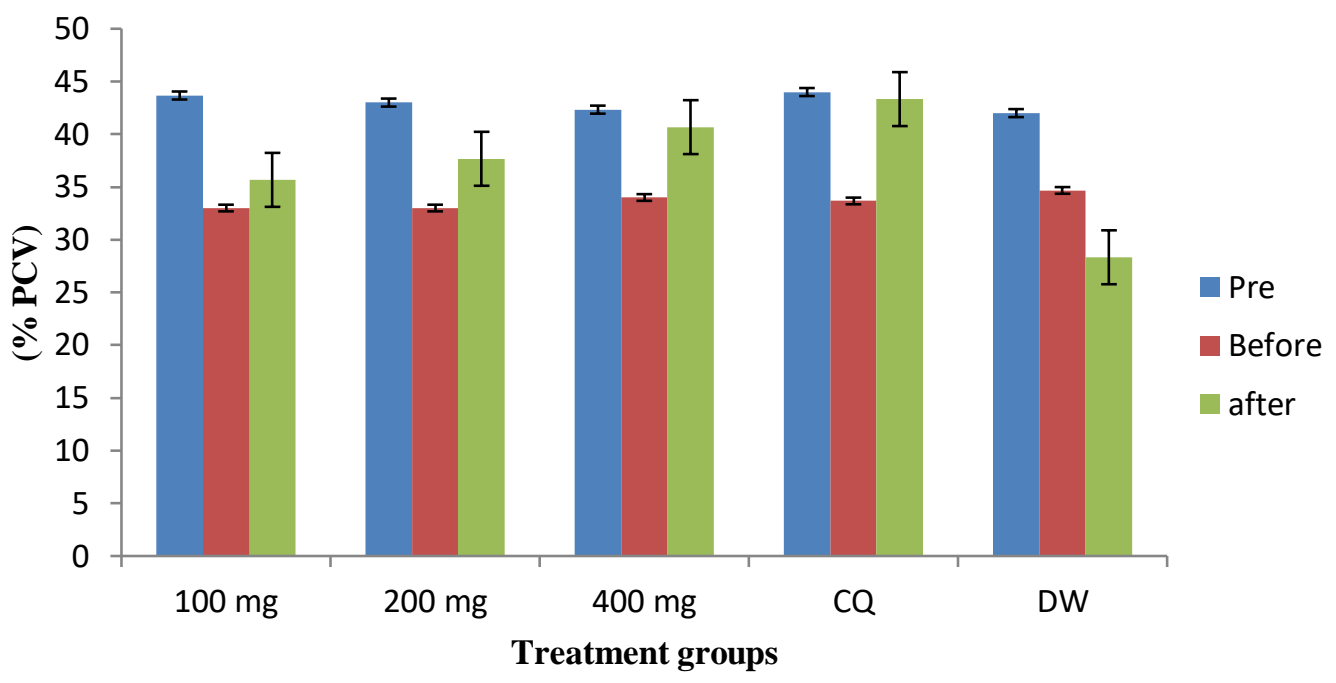

Figure 3: Effect of ethyl-acetate extract of Cassia occidentalis leaf on percentage packed cell volume (\% pcv) of Plasmodium berghei-infected mice. Pre: Before induction of Plasmodium bergbei, Before: After induction of Plasmodium bergbei and before treatment, after: After treatment, $\mathrm{CQ}: 5 \mathrm{mg} / \mathrm{kg}$ Chloroquine, DW: Distilled water.

\subsection{Mean Survival Time}

The mean survival time of mice for both suppressive and Curative studies are shown in Table 3. Treatment with Ethyl-acetate extract of Cassia occidentalis leaf significantly $(p<0.05)$ caused a dose-dependent increase in the survival days of the animals in both the suppressive and curative treatment regimen.

Table 3: Mean survival time of mice for suppressive and curative antiplasmodial tests

\begin{tabular}{c|c|c|}
\hline $\begin{array}{c}\text { Extract Dose } \\
\text { (mg kg-b.wt) }\end{array}$ & $\begin{array}{c}\text { Suppressive } \\
\text { (Days) }\end{array}$ & $\begin{array}{c}\text { Curative } \\
\text { (Days) }\end{array}$ \\
\hline $\mathbf{1 0 0}$ & $6.00 \pm 0.58^{\mathrm{a}}$ & $7.67 \pm 1.45^{\mathrm{a}}$ \\
\hline $\mathbf{2 0 0}$ & $12.33 \pm 1.45^{\mathrm{b}}$ & $15.00 \pm 1.73^{\mathrm{b}}$ \\
\hline $\mathbf{4 0 0}$ & $26.33 \pm 2.03^{\mathrm{c}}$ & $25.33 \pm 1.86^{\mathrm{c}}$ \\
\hline $\begin{array}{c}\mathbf{5} \\
\text { (Chloroquine) }\end{array}$ & $29.00 \pm 1.00^{\mathrm{c}}$ & $29.00 \pm 1.00^{\mathrm{c}}$ \\
\hline Distilled water & $4.33 \pm 0.88^{\mathrm{a}}$ & $5.00 \pm 1.53^{\mathrm{a}}$ \\
\hline
\end{tabular}

Data are presented as Mean \pm SEM of three replicates and values with different superscript along each column are significantly different. $\mathrm{mgkg}^{-1} \mathrm{~b} . \mathrm{wt}$ : $\mathrm{mg}$ per kilogram body weight

\subsection{Discussion}

The Ethyl-acetate extract of Cassia occidentalis leaf from this study contains various phytochemicals, some of which have been implicated in antimalarial studies. Therefore, the observed antimalarial activity in the extract-treated group may be attributed to its high alkaloid and flavonoid contents. Previous works have also shown the antimalarial activity of alkaloids and flavonoids in plants $[22,23]$. The antimalarial activity observed in this study could be due to the single or combined effect of these compounds although no active principle has been identified. Flavonoids are well known for their diverse physiological properties, which include antiinflammatory, anti-carcinogenic and anti-parasitic properties [24].

With reference to the $\mathrm{LD}_{50}$ values based on acute oral toxicity recommended by the Globally Harmonized System of classification and labelling of chemical [25], $\mathrm{LD}_{50}>5000 \mathrm{mg} / \mathrm{kg}$ was not classified, had no specified label and was said not to be harmful when swallowed. Hence, the $L_{50} \geq 5000 \mathrm{mg} / \mathrm{kg}$ Ethyl-acetate extract of Cassia occidentalis is an indication that the extract may be safe for human consumption, therefore, confirming the folkloric claim that Cassia occidentalis leaf is not harmful in humans. Also, the high safety profile may have been responsible for its widespread use in different ethno-therapeutic interventions.

The significant chemosuppression observed in the extract-treated with $400 \mathrm{mg} / \mathrm{kg}$ on day 5 is in agreement with the traditional use of the plant as a herbal medication against malaria in many parts of Nigeria. Although there was no significant difference $(P>0.05)$ in chemosuppression between the groups that received $200 \mathrm{mg} / \mathrm{kg}$ and $400 \mathrm{mg} / \mathrm{kg}$ body weight, a dose of $400 \mathrm{mg} / \mathrm{kg}$ might as well be enough to bring about the desired effect. The observed higher efficacy of the standard drug than extract-treated groups may be due to non-selectivity of the extract or slow 
absorption and poor bioavailability of the extract [26, 27].

The Ethyl-acetate extract of Cassia occidentalis leaf also showed significant antiplasmodial activity on established infection. Although, the group treated with $5 \mathrm{mg} / \mathrm{kg}$ body weight of chloroquine (standard drug) had the highest percentage cure, however, there was no significant difference $(P>0.05)$ in cure between it and the group treated with $400 \mathrm{mg} / \mathrm{kg}$ of the extract. Present findings are consistent with earlier reports by Odeku et al. (2008) [28] and Idowu et al. (2010) [29], who demonstrated the curative potentials of Nigeria medicinal plants against established plasmodial infections.

The curative test was supported by the haematological test which showed a significant reduction in \% PCV after Plasmodium berghei induction and increased significantly after treatment in the extract and chloroquine treated groups in a dose-dependent pattern. However, for the infected not treated group, the \% PCV but reduced significantly throughout the experimental period showing that the mice were anaemic, which is an important feature of plasmodium infections [30]. Several factors contribute to the development of anaemia among which is increased lipid peroxidation as a consequence of oxidative damage to the membrane component of erythrocytes [31]. The observed improvement in the $\%$ PCV for the groups treated with the extract could imply that the extract contains some anti-oxidative components that could prevent the Plasmodium berghei associated oxidative damage to erythrocytes components [32].

The antiplasmodial activity corroborated with the mean survival time of the experimental mice. For the untreated mice, the parasite count increased daily until the death of the animals (highest mortality); higher mortality was also observed in the group treated with the lowest dose of extract compared to the higher doses and the standard drug (Chloroquine). This finding is similar to that obtained in a study conducted by Akuodor et al. [33].

\subsection{Conclusion}

This study has revealed that Ethyl-acetate extract of Cassia occidentalis has been able to suppress and decrease Plasmodium berghei parasites in mice. The antiplasmodial activity demonstrated by the extract could be attributed to the presence of some plant secondary metabolites such as phenols, alkaloids, flavonoids, tannins and saponins. The findings in this study provide scientific proof of the folkloric use of Cassia occidentalis in the treatment of malaria.

\section{Acknowledgements}

The authors are grateful to the Laboratory Technologists, department of Biochemistry, Federal University of Technology, Minna.

\section{Funding}

This work was supported by the contributions of each author.

\section{Author contributions}

Authors UMB and IRB conceived the study. UMB, AH and IRB participated in the design and quality assessment of the study. Author IRB and AH partook in the selection and extraction of the plant sample used. Author IRB carried out the experiment, with the assistance of the Laboratory Technologists and the other authors. IRB drafted the manuscript, with significant input from UMB. All authors proofread the manuscript and made inputs. All authors approved the final version of the article for publication.

\section{Conflicts of interest}

The authors declare that they have no competing interests.

\section{References}

1. World Health Organisation (2021). World malaria report 2021. Geneva, CC BY-NC-SA 3.0 IGO.

2. Snow, R. W., Guerra, C. A., Noor, A. M., Myint, H. Y and Hay, S. I. (2005). The global distribution of clinical episodes of Plasmodium falciparum malaria. Nature, 434, 214-217.

3. Sanket, S and Sarita, G. (2009). In vitro Antiplasmodial activity of Enicostemma littorate. American Journal of Infectious Diseases, 5(3), 259-262.

4. Boland, P. (2001). Drug resistance in malaria. WHO/CDS/CSR/DRS, World HealthOrganization.http://www.who.int/entity/c sr/resources/publications/drugresist/malaria.pdf.

5. Fidock, D. A., Rosenthal P. J., Croft S. L., Brun, R. and Nwaka, S. (2004). Antimalarial drug discovery: Efficacy models for compound screening. Natural Reserved Drug Discovery, 3, 509-520.

6. Khozirah, S., Noor-Rain, A., SitiNajila, M. J., Imiyabir, Z. and Madani, L. (2011). In vitro Antiplasmodial properties of selected plants of Sabah. Pertanika Journal of Science \& Technology, 19(1), 11-17.

7. Peter, L. T and Anatoli, V. K. (1998). The current Global Malaria situation: Malaria parasite Biology, pathogenesis and protection. American Society of Microbiology press, Washington DC, 686, 356362.

8. Zirihi, G.N., Mambu, L., Guede-Guina, F., Bodo, B and Grellier, P. (2005). In vitro antiplasmodial 
activity and cytotoxicity of 33 West African plants used for treatment of malaria. Journal of Ethnopharmacology, 98, 281-285.

9. Kirtikar K. R. and Basu, B. D. (1987). Indian Medicinal Plants. Vol. 1-4. Lalit Mohan Basu, Allahabad, Jayyed Press, New Delhi, India.

10. Bin-Hafeez, B., Ahmad, I., Haque, R. and Raisuddin, S. (2001). Protective effect of Cassia occidentalis L. on cyclophosphamide-induced suppression of humoral immunity in mice. Journal of Ethnopharmacology, 75, 13-18.

11. Evans, C. E., Aderotimi, B. and Adeyemo, S. O. (2002). Efficacy of some Nupe medicinal plants against Salmonella typhi: an in vitro study. Journal of Ethnopharmacology, 80(1), 21-24.

12. Tona, L., Cimanga, R. K., Mesia, K., Musuamba, C. T., De Bruyne, T., Apers, S., ... \& Vlietinck, A. J. (2004). In vitro antiplasmodial activity of extracts and fractions from seven medicinal plants used in the Democratic Republic of Congo. Journal of Ethnopharmacology, 93(1), 27-32.

13. Canadian Council on Animal Care (CCAC) (1997). Guidelines on: Animal use and Protocol review. http://www.ccac.ca/Document/Standards/Guidel ines/Protocol Review.pdf.

14. Ugwu, B. U., Okogun, J. I., Kabiru, A. Y. and Ogbadoyi, E. O. (2011). Evaluation of therapeutic potentials of stem bark extracts of Annona senegalensis in experimental Trypanosoma brucei brucei infection in mice. British Journal of Pharmacology and Toxicology, 2(2), 63-70.

15. Kabiru, Y. A., Okolie, N. L., Muhammad, H. L and Ogbadoyi, E. O. (2012). Preliminary studies on the antiplasmodial potency of aqeous and methanol extracts of Eucalyptus camadulenesis leaf. Asian Pacific Journal of Tropical Disease, 2, 5809-5814.

16. Talukdar, A. D., Choudhury, M. D., Chakraborty, M., \& Dutta, B. K. (2010). Phytochemical screening and TLC profiling of plant extracts of Cyathea gigantea (Wall. Ex. Hook.) Haltt. and Cyathea brunoniana. Wall. ex. Hook (Cl. \& Bak.). Assam University Journal of Science and Technology, 5(1), 70-74.

17. Lorke, D. A. (1983). A new approach to practical acute toxicity testing. Archives of Toxicology, 53, 275-289.

18. Peters, W. (1967). Rational methods in the search for antimalarial drugs. Transition of Royal Society of Tropical Medicine and Hygiene, 61, 400-410.
19. Saidu, K., Onah, J., Orisadipe, A. A., Wambebe C and Gamaniel, K. (2000). Antiplasmodial, analgesic and anti-inflammatory activities of the aqueous extract of thestem bark of Erythrina senegalensis. Journal of Ethnopharmacology, 71, 275-280.

20. Ryley, J. F and Peters, W. (1970). The antimalrial activity of some quinolone esters. American Journal of Tropical Medicine and Parasitology, 84, 209-222.

21. Dacie, J. V., \& Lewis, S. M. (1991). Practical Haematology, $7^{\text {th }}$ edition. Churchill Livingstone, Edinburgh.

22. Balogun, E. A., Adebayo, J. O., Zailani, A. H., Kolawde, O. M and Ademowo, O. G. (2009). Activity of ethanolic extract of clerodendrumviolaceum leaves against Plasmodium berghei inmice. Agric and Biology Journal of North America, 1, 307-312.

23. Uzor, P. F. (2020). Alkaloids from plants with Antimalarial Activity: A Review of recent studies. Evidence-Based Complementary and Alternative Medicine, 2020, 1-17.

24. Hilou, A., Nacoulmaa, O. G and Guiguemde, T. R. (2006). In vivo antimalarial activities of extractsfrom Amaranthusspinosus $L$. and Boerhaaviaerecta $L$. in mice. Journal of Ethnopharmacology, 103, 236-240.

25. Anonymous, D. (2003). Globally Harmonized System of Classification and labeling of Chemicals. Available at http//www.unece.org/trans/danger/public/ghs/o fficialtext.htmL.

26. Iyiola, O. A., Tijani, A. Y., \& Lateef, K. M. (2011). Antimalarial activity of ethanolic stem bark extract of. Asian Journal of Biological Science, 4(3), 235-243.

27. Uraku, A. J., Okaka, A. N. C., Ibiam, U. A., Agbafor, K. N., Obasi, N. A., Ajah, P. M., Obasi, O. U. and Nwalo, F. N. (2015). Antiplasmodial Activity of Ethanolic Leaf Extracts of Spilanthes uliginosa, Ocimum basilicum (Sweet Basil), Hyptis spicigera and Cymbopogon citratus on Mice Exposed to Plasmodium berghei Nk 65. International Journal of Biochemistry Research \& Review 6(1), 28-36.

28. Odeku, O. A., Adegoke, O. A and Majekodunmi, S. O. (2008). Formulation of the extract of the stem bark of Alstonia boonei as tablet dosage form. Tropical Journal of Pharmaceutical Research, 7, 987- 994.

29. Idowu, O. A., Soniran O. T., Ajana, O. and Aworinde, D. O. (2010). Ethnobotanical survey of 
antimalarial plants used in Ogun State, Southwest Nigeria. African Journal of Pharmacy and Pharmacology, 4, 055-060.

30. Becker, K., Tilley, L., Vennerstrom, J. L., Roberts, D., Rogerson, S., \& Ginsburg, H. (2004). Oxidative stress in malaria parasite-infected erythrocytes:

interactions. International parasitology, 34(2), 163-189. host-parasite journal for

31. Omodeo-Sale, F., Motti, A., Basilico, N., Parapini, S., Olliaro, P., \& Taramelli, D. (2003). Accelerated senescence of human erythrocytes cultured with Plasmodium falciparum. Blood, 102(2), 705-711.

32. Ebenyi, L. N., Yongabi, K. A., Ali, F. U., Ominyi, M. C., Anyanwu, C. B., Benjamin, E. and Ogbanshi, M. E. (2021). Effect of Aqueous Leaf Extract of Jatropha tanjorensis on parasitaemia and haematological parameters in mice infected with Plasmodium berghei. Nigeria Journal of Biotechnology, 38(1), 146-153.

33. Akuodor, G. C., Idris-Usman, M, Ugwu, T. C., Akpan, J. L., Ghasi, S. I and Osunkwo, U. A. (2010). In vivo Schizonticidal activity of ethanolic leaf extract of Gongronema latifolium on Plasmodium berghei in mice. African Journal of Biotechnology, 9(5), 2316-2321.

\section{Submit your article to AROC JOURNALS \\ -AROC in Pharmaceutical and Biotechnology -AROC in Agriculture \\ -AROC in Food and Nutrition \\ -AROC in Natural Products Research \\ -BIOMED Natural and Applied Science \\ Via https://arocjournal.com/}

Copyright (C) 2022 Umar et al. This is an open access article distributed under the terms and conditions of the Creative Commons Attribution License (CC BY) which allowed unrestricted download, distribution and reused as long as the original authors are properly cited. 